\title{
Response of tapered piles in cohesionless soil based on model tests
}

\author{
Suman Manandhar, *Noriyuki Yasufuku, Kiyoshi Omine, and Taizo Kobayashi \\ Department of Civil and Structural Engineering, \\ Geotechnical Laboratory, Kyushu University, Fukuoka, 819-0395 Japan \\ (*Email: yasufuku@civil.kyushu-u.ac.jp)
}

\begin{abstract}
This paper describes model tests of different types of tapered piles in cohesionless soils. Chromium plated three steel piles, one straight and two taper-shaped piles of same length and pile tip diameters have been executed for pile loading test in a downward frictional mode. Two different types of model grounds have been prepared for the test. Relative densities of 80 $\%$ and $60 \%$ have been modeled to penetrate piles in two different types of sands to observe the effectiveness of skin frictions of different types of piles. The response of tapered piles has shown that the skin friction has increased with increasing the tapering angle at normalized settlement ratio of 0.4 . High density ground yields higher skin friction when the maximum tapered pile was penetrated. Slightly increased tapering angle of the pile affects remarkably on the skin friction with compared to conventional straight cylindrical pile even at small 0.1 settlement ratios.
\end{abstract}

Keywords: Tapered piles, skin friction, relative density, cohesionless soil

Received: December 18, 2009

Revision accepted: April 28, 2010

\section{INTRODUCTION}

The bearing capacity of tapered piles is particularly affected through roughness and shape of pile surface, angle of tapering, and volume of soil displaced by the pile penetration. When pile transfers load to the ground, on the shaft of the pile, horizontal earth pressures act with increasing vertical load in a downward frictional mode resulting mobilization of ultimate soil pile adhesion.

The overall resistance of pile is increased by a factor of 5-9, and increases the resistance with mobilizing deeper towards depth (Dmokhovskii 1927). Therefore, many authors keep in interest on the investigation of the tapered piles such as pyramidal, conical and wedge-shaped piles. In addition, tapered piles are economically feasible and labor for deep foundation. The axial pile capacity as the load corresponding to a displacement is equal to $10 \%$ of the pile diameter (Terzaghi 1942). The bearing mechanism of the tapered pile governs high capacity when transferred to the soil with compared to single pile. The analytical method was applied to evaluate the axial capacity of the tapered piles and accounted a substantial increase of axial compressive capacity of the tapered piles over straight piles when the tapered piles were driven into cohesionless soil (Norlund 1963). Nevertheless, the accurate model to derive the axial capacity of the tapered pile in context to deep foundation was not identified. The axial deformation for initial slip is $1-$ $4 \%$ of the pile radius in clay while the deformation can be as low as $0.25 \%$ in sand (Fleming et al. 1985). The capacity of the pile had increased with increasing tapering angle of $1 \%$ or more, for a given length of embedment, between $1 \frac{1 / 2}{2}$ and
$2^{1 / 2}$ times (Peck 1958). Yasufuku and Ochiai (2006) improved the model of soil-pile interaction mechanism based on direct shear mode at critical state friction angle to verify the skin friction of non-displacement of piles. Manandhar et al. (2009) elucidated that the mechanism of the tapered piles has good pressing effects towards the depth of penetration. Moreover, tapered piles are economically feasible for deep foundation. Numerous benefits have added keen interest on researching and checking the phenomena of the tapered piles in context to skin friction when penetrating into cohesionless soil. The main theme of this paper is to render the response of skin frictions of tapered piles compared to straight cylindrical piles based on model pile load test results.

\section{OUTLINE OF GEOTECHNICAL PARAMETERS}

Two different types of air-dried silica sands and testing apparatus have been used to evaluate the skin friction of tapered piles. Numerous tests have been performed to meet the objective of the work. K-7 sand and Toyoura sand (TO) were modeled in two entirely different environments. Three model chromium plated steel piles (one straight pile and two different tapered-shaped piles) were set up in the pile load equipment. Advanced and sophisticated instruments were used to find the properties of aforementioned silica sands.

\section{Index parameters}

Laser Diffraction Particle Size Analyzer prepared by Shimadzu Company of Japan was used to carry out grain size analyses of K-7 sand and TO sands, respectively. Both 


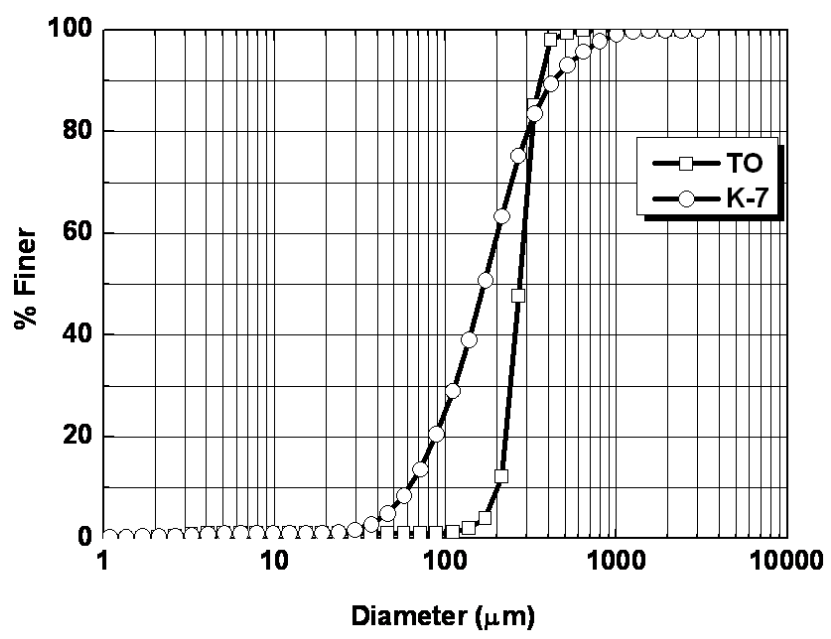

Fig. 1: Gradation of sands

Table 1: Geotechnical parameters of sand

\begin{tabular}{|c|c|c|}
\hline Descriptions & TO & $\mathrm{K}-7$ \\
\hline Density of particles, $\mathrm{s}\left(\mathrm{g} / \mathrm{cm}^{3}\right)$ & 2.65 & 2.622 \\
\hline Maximum density, $\max \left(\mathrm{g} / \mathrm{cm}^{3}\right)$ & 1.64 & 1.597 \\
\hline Minimum density, $\min \left(\mathrm{g} / \mathrm{cm}^{3}\right)$ & 1.34 & 1.19 \\
\hline Density at $\mathrm{D}_{\mathrm{r}} 80 \%, \quad 80\left(\mathrm{~g} / \mathrm{cm}^{3}\right)$ & 1.58 & 1.516 \\
\hline Density at $D_{\mathrm{r}} 60 \%, \quad 60\left(\mathrm{~g} / \mathrm{cm}^{3}\right)$ & 1.52 & 1.431 \\
\hline Maximum void ratio, $\mathrm{e}_{\max }$ & 0.98 & 1.202 \\
\hline Minimum void ratio, $\mathrm{e}_{\min }$ & 0.62 & 0.641 \\
\hline Void ratio at $\mathrm{D}_{\mathrm{r}} 80 \%$, e 80 & 0.68 & 0.728 \\
\hline Void ratio at $D_{r} 60 \%$, e 60 & 0.74 & 0.831 \\
\hline Uniformity coefficient, $\mathrm{U}_{\mathrm{c}}$ & 1.40 & 4.0 \\
\hline Coefficient of curvature, $\mathrm{U}_{\mathrm{c}}$ & 0.86 & 1.21 \\
\hline Percent fines, $\mathrm{F}_{\mathrm{c}}(\%)$ & 1.10 & 14 \\
\hline Peak stress, deg) & 42 & 47 \\
\hline Critical stress state, 'cv deg) & 32 & 34 \\
\hline
\end{tabular}

specimens are uniformly graded sands with various degrees of fines. K-7 sand contains more fines with compared to TO sand (Fig. 1). Similarly, index parameters such as density of particles (specific gravity), maximum and minimum densities, density at required modeled ground (such as density of K-7 sand at $60 \%$ and density of Toyoura sand at $80 \%$ ) were computed and tabulated in Table 1. Maximum and minimum void ratios of K-7 sand and Toyoura sand (TO) at their corresponding relative densities were computed and tabulated accordingly.

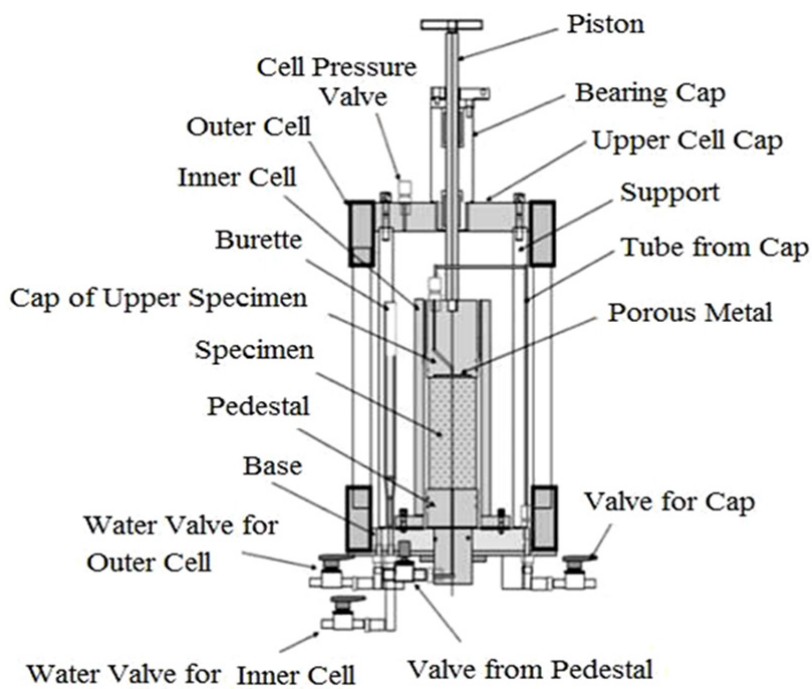

Fig. 2: Typical tri-axial load cell

\section{Strength parameters}

Different soils have different strength parameters. When these soils stay at the different settling environments, the strength parameters such as angle of internal friction and cohesion will change according to the density or compactness of the ground. The peak and critical state friction angles have been computed using advanced tri-axial apparatus (Table 1). The apparatus constitutes two cells; inner cell and outer cell. Sample is prepared in dry condition at required relative density. This tri-axial consolidation drained (CD) test has a facility to measure volume change without saturating soil specimen. Compression provides change in volume $(\mathrm{dV})$ in sample by subtracting change in volumes of water level in the inner cell and outer cell.

$$
\mathrm{dV}=\mathrm{S}_{\mathrm{w}} \mathrm{dh}_{\mathrm{w}}-\mathrm{S}_{\mathrm{cap}} \mathrm{dh}_{\mathrm{cap}}
$$

Where, $S_{w}$ : surface area of water in inner cell, $d_{\mathrm{w}}$ : the change in height of water level in the inner cell, $S_{\text {cap }}$ : surface area of cap and $\mathrm{dh}_{\text {cap }}$ : the change in height of cap (Fig. 2). This apparatus has advantages to perform experiment in a short span of time. In the laboratory, K-7 and TO sands were tested under relative densities of $60 \%$ and $80 \%$, respectively at confining pressure of $50 \mathrm{KPa}$.

\section{Preparation of model ground for pile load test}

Pile load apparatus has a facility to perform pile penetration test under required relative density. The cylindrical chamber is $1000 \mathrm{~mm}$ in height and $750 \mathrm{~mm}$ in diameter. The chamber is then equipped with air cylinder, displacement gauge, loading jack and loading cell. Load cell is then connected to rotation driving worm where pile cap has been adjusted. Upper plate transfers overburden pressure to the model ground vertically (Fig. 3).

The chromium plated steel model piles with equal lengths of $500 \mathrm{~mm}$ and same tip diameters of $25 \mathrm{~mm}$ were used for pile 


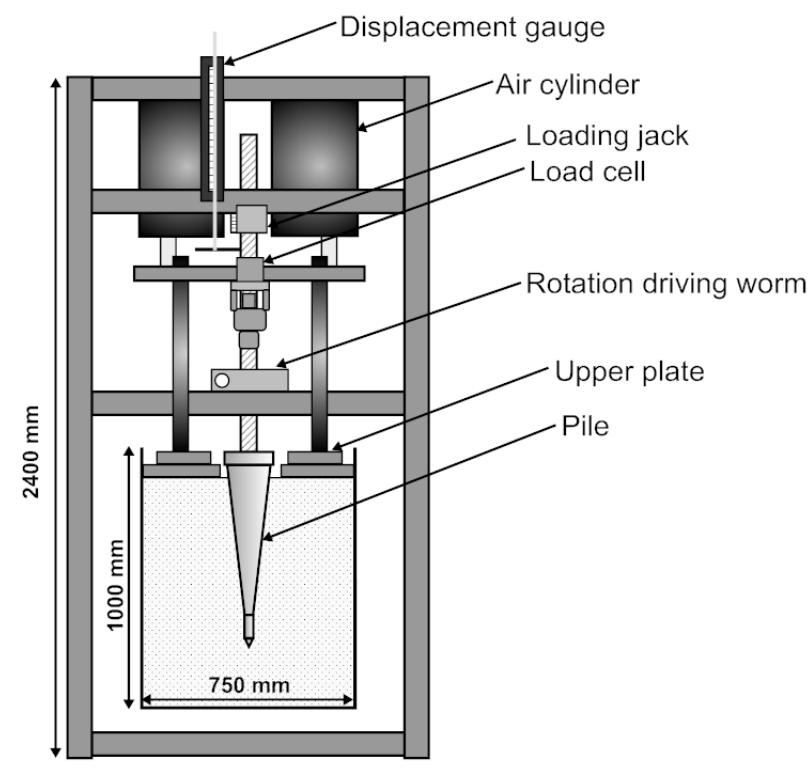

Fig. 3: Pile load test apparatus

penetration. Three different types of piles; one straight (S) and two taper-shaped (T1 and T2) with different axial diameters at the pile top were used to perform the model pile load tests (Fig. 4 and Table 2).

First of all maximum and minimum dry densities of K-7 and Toyoura sands were determined by the method proposed by Japanese Industrial System (JIS A 1224) and Japanese Geotechnical Standards (JGS 0161). The relative density $\left(\mathrm{I}_{\mathrm{D}}\right) 60 \%$ of K-7 sand and $80 \%$ of Toyoura sand were calculated accordingly (Table 1). A sample preparation method using multiple sievings can give a wide range of specimen density by height of fall and nozzle diameter (Miura and Toki 1982). Thus, air-dried silica sand was fallen freely through sieve with an average nozzle area of $493 \mathrm{~mm}^{2}$ on the determined height. Different nozzle area and/or nozzle diameter significantly changes the densification of the ground. In this case, height of falling was determined to make the required relative density of the ground keeping constant area of nozzle (Fig. 5). Various relative densities of sands at different heights and average relative density of sands were clearly shown (Figs. 6a and 6b). K-7 sand was fallen freely from the height of $1400 \mathrm{~mm}$ and spread uniformly on the chamber by rotating homogenously. Height was controlled by lifting the sieving apparatus gradually. When soil was filled nearly $710 \mathrm{~mm}$ from the bottom, pile was set up at the centre of the chamber. Then, four transducers were set up at the equal interval of $60 \mathrm{~mm}$ from one to another. First transducer was installed close to pile tip. These transducers measure the earth pressures laterally. From the center of the pile earth pressure sensors 1, 2, 3 and 4 were installed at $30 \mathrm{~mm}, 90 \mathrm{~mm}, 150 \mathrm{~mm}$, and $210 \mathrm{~mm}$ respectively (Fig. 7).

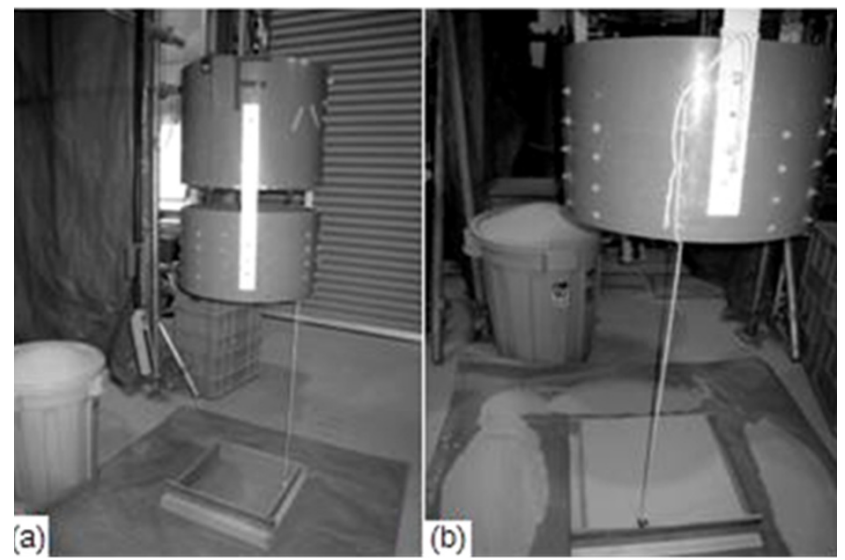

Fig. 4: $I_{D}$ determination by free falling sand

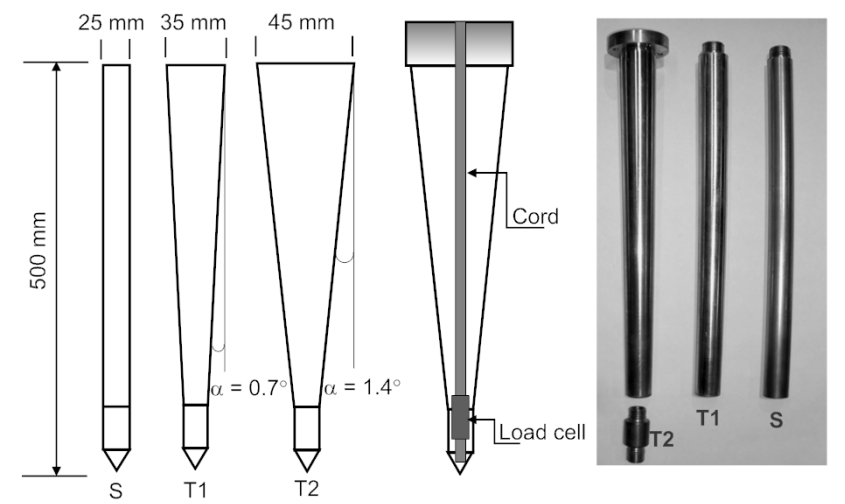

Fig. 5: Total geometrical configuration of piles (figures are not in scale); right side photo represents model piles

Afterwards, soil was poured up to $930 \mathrm{~mm}$ from the bottom of the chamber. Then upper part was carefully closed by plate and load cells at pile head and tip were connected. The whole arrangement was linked with data logger and computer.

Finally, pneumatic air pressure of $50 \mathrm{KPa}$ was set up to furnish the overburden pressure $\left(s_{v}\right)$ vertically through upper plate. After setup the apparatus, pile was penetrated down up to $200 \mathrm{~mm}$ as a initial preparation phase of pile model test at the rate of $5 \mathrm{~mm} / \mathrm{min}$. To perform the test, it is necessary to settle the ground sufficiently such that redundant data would not appear. Minimum fifteen hours time is required to settle down the pile in the ground for stress relaxation. After relaxing the compression effect, pile load test was performed up to 0.4 settlement ratio at the constant rate of $5 \mathrm{~mm}$ per minute. Here, the model ground was prepared to facilitate cast-inplace pile condition. The tests were constricted to single pile and two taper-shaped piles. Same procedures were considered to perform cast-in-place pile model test of Toyoura sand at $I_{D} 80 \%$ by controlling the height of falling sand from $700 \mathrm{~mm}$ above the ground. 


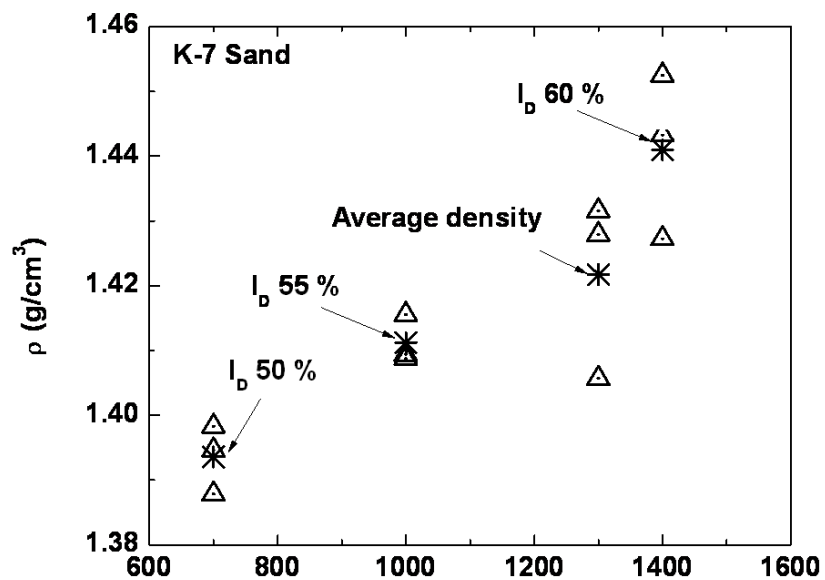

(a) Height of fall ( $\mathrm{mm}$ )

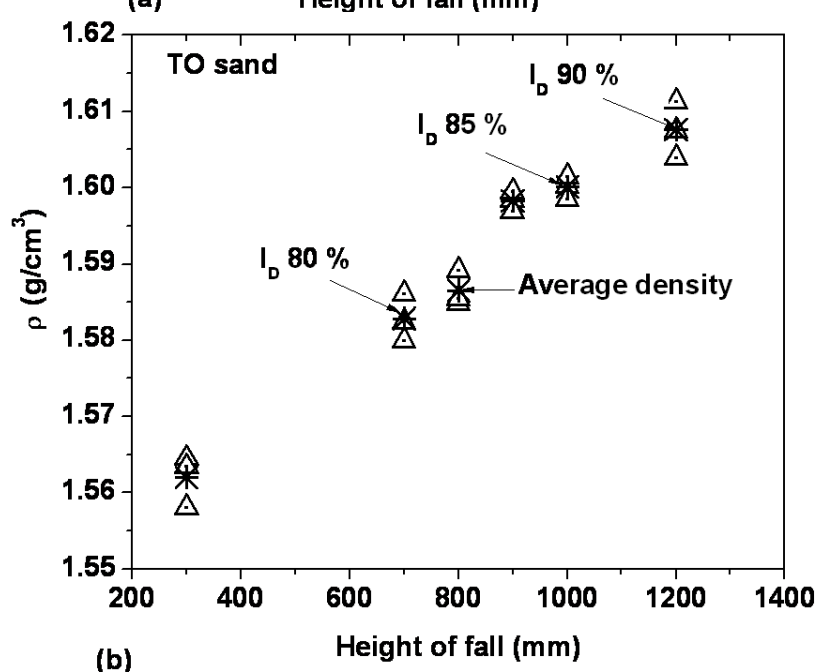

Fig. 6: Determination of relative densities falling through area of nozzle $493 \mathrm{~mm}^{3}$ sieve (a) K-7 sand (b) Toyoura sand

The model pile load test has an advantage that the load at pile tip $\left(\mathrm{P}_{\mathrm{B}}\right)$, load at pile head $\left(\mathrm{P}_{\mathrm{T}}\right)$ and lateral earth pressure can be directly measured through the test. The differences of load at pile head and pile tip gives the skin friction $\left(\mathrm{P}_{\mathrm{S}}\right)$ around the pile which can be measured in $\mathrm{kN}$. Mathematically, it can be expressed as:

$$
\mathrm{P}_{\mathrm{S}}=\mathrm{P}_{\mathrm{T}}-\mathrm{P}_{\mathrm{B}}
$$

The obtained results were plotted in graph to understand the response of skin friction of pile. Fig. 8 is a conceptual example of the end bearing capacity, the total capacity and the skin friction.

\section{BASIC THEORY}

The shaft resistance is used for the evaluation of skin friction at require depth. Norlund (1963) has expressed the skin friction of the pile, is expressed in the general form below:

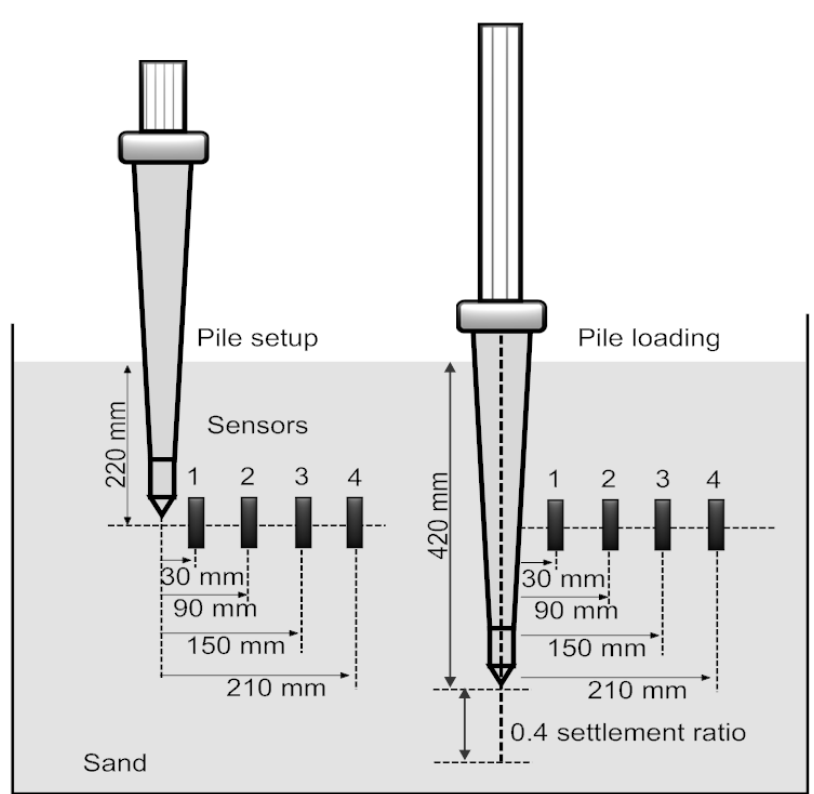

Fig. 7: Cast-in-place pile model setup and pile loading up to 0.4 settlement ratio

Table 2: Configurations of piles

\begin{tabular}{cccccc}
\hline Piles & $\mathbf{L}$ & $\mathbf{D}_{\mathbf{t}}$ & $\mathbf{d}$ & $\boldsymbol{\omega}$ & \\
\hline & $\mathrm{mm}$ & $\mathrm{mm}$ & $\mathrm{mm}$ & $\%$ & $?$ \\
$\mathrm{~S}$ & 500 & 25 & 25 & 0.00 & 0.00 \\
$\mathrm{~T} 1$ & 500 & 35 & 25 & 2.50 & 0.70 \\
$\mathrm{~T} 2$ & 500 & 45 & 25 & 5.00 & 1.40
\end{tabular}

$D$ : pile head diameter; $d$ : tip diameter; $\bar{\omega}$ : degree of tapering; $\alpha$ : angle of tapering

$$
\mathrm{f}_{\mathrm{s}}=\int_{0}^{\mathrm{L}} \mathrm{K}_{\delta} \mathrm{p}_{z} \sin (\alpha+\delta) \sec \alpha \mathrm{C}_{z}
$$

Where, $f_{s}$ is skin friction of the pile at the require depth, $p_{z}-$ effective overburden pressure, L- depth from ground surface to pile point, $\mathrm{Z}$ - depth below ground surface, $\mathrm{K}_{\delta}-\mathrm{a}$ dimensionless factor defined as the ratio of the resultant of the effective normal and shear stresses at the incipient failure plane passing through a point and the effective overburden pressure at that point, $\alpha$ - the tapering angle of the pile, $\delta$ - the friction angle on the surface of sliding including the pile shaft, and $\mathrm{C}_{\mathrm{z}}$ - the minimum perimeter encircling the pile (Fig. 9).

In other words, the skin friction at the required depth is the sum of pile to soil adhesion and friction factors by the following equation: 
Response of tapered piles in cohesionless soil based on model tests

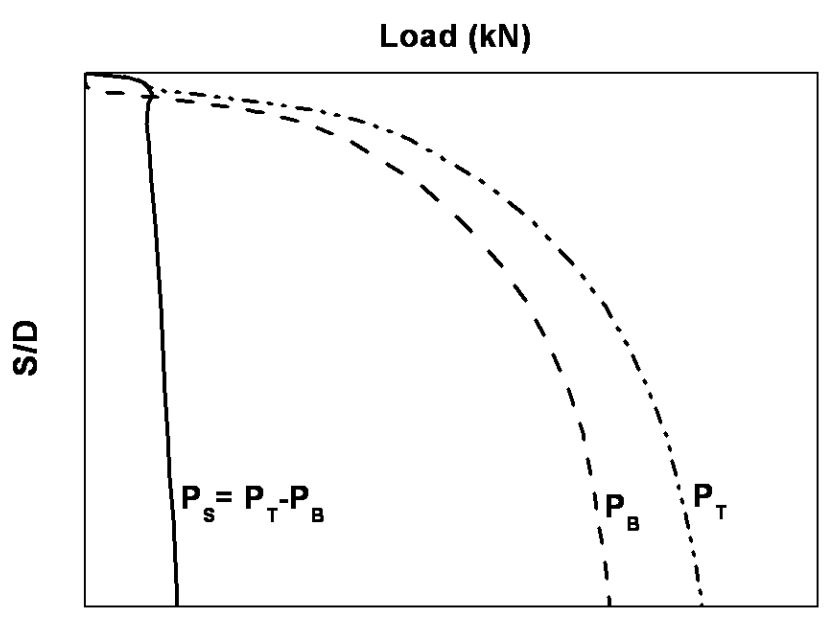

Fig. 8: Concept of skin friction of pile

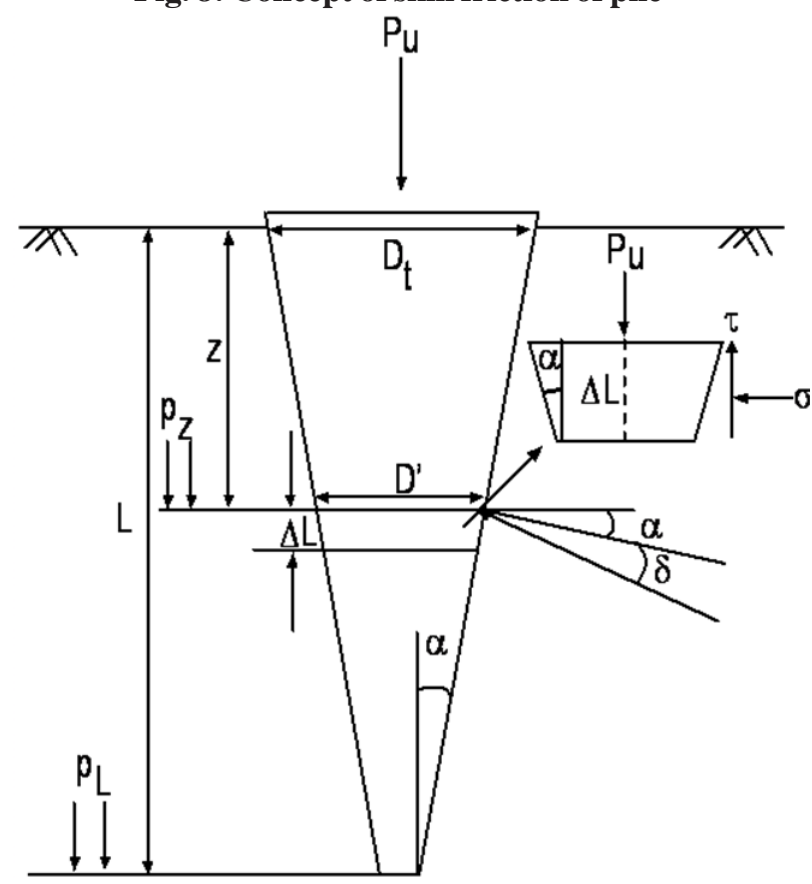

Fig. 9: Geometry of pile penetration

$$
\mathrm{f}_{s}=\mathrm{c}_{\delta}^{\prime}+\sigma_{\mathrm{h}}^{\prime} \tan \phi_{\delta}^{\prime}
$$

Where $c_{-}^{\prime}$ and $\phi_{-}^{\prime}$ are arhesion and friction parameters between pile and soil, and $\sigma_{h}$ is the horizontal effective stress acting on the pile.

In the practical design, the axial pile capacity is estimated for a settlement of approximately $10 \%$ of the pile diameter. Therefore, in the case of practical design, the settlement criterion for drifting maximum $\mathrm{f}_{\mathrm{s}}$, it is practicable to use the strength parameters at the critical state corresponding to large displacements, such that:

$$
\begin{aligned}
& c_{5}^{\prime}=0 \\
& \phi_{5}^{\prime}=\phi_{\mathrm{cv}}^{\prime}
\end{aligned}
$$

Table 3: Model pile load test results

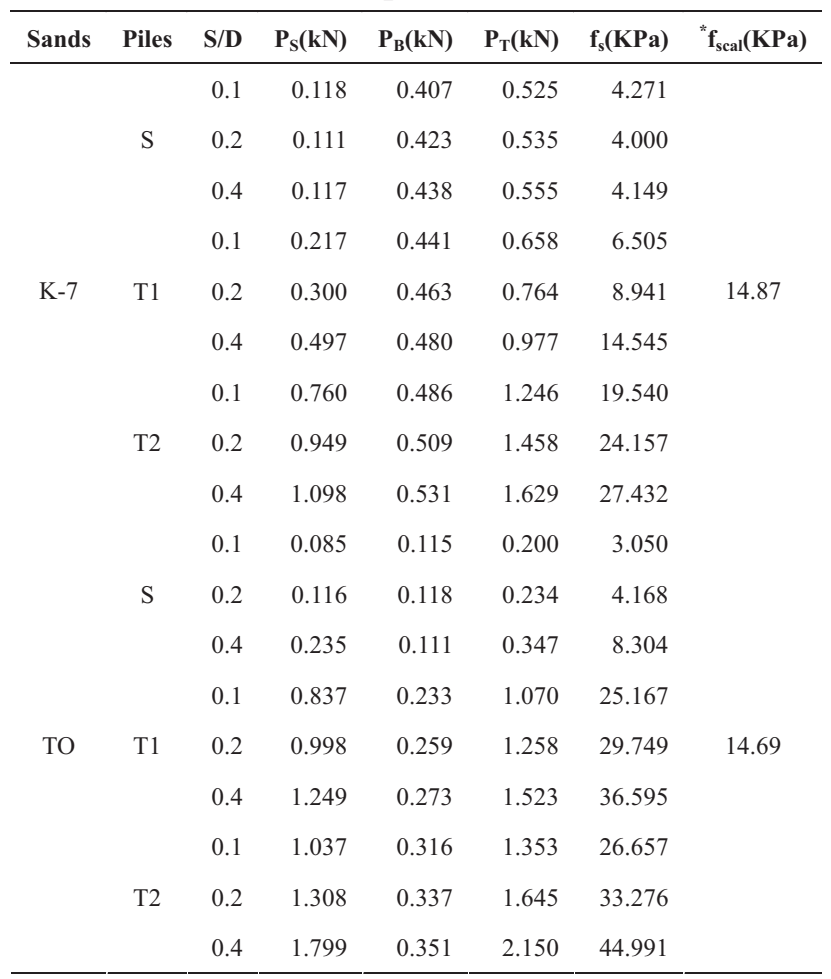

$f_{\text {scal }}:$ calculated unit skin friction using Equation (8)

Where, $\phi_{c v}^{\prime}$ is a friction angle at the critical state independent on density and overburden pressure as well as values of minimum strength, which is applicable for design purpose as, proposed by Yasufuku et al. (1998, 2001).

The horizontal effective stress depends on overburden pressure such that:

$$
\sigma_{\mathrm{h}}^{\prime}=\mathrm{K} \sigma_{\mathrm{v}}^{\prime}
$$

Where, $\mathrm{K}$ is the coefficient of horizontal effective stress which depends on horizontal effective stress. For simplicity, modifying Equation (4) with the help of Equations (5) and (6), it can be represented as:

$$
\begin{aligned}
& \mathrm{f}_{\mathrm{s}}=\mathrm{K}_{0} \sigma_{\mathrm{v}}^{\prime} \tan \phi_{\mathrm{cv}}^{\prime} \cdots \cdots \\
& \mathrm{K}_{0}=\left(1-\sin \phi_{\mathrm{cv}}^{\prime}\right) . .
\end{aligned}
$$

Where $\mathrm{K}_{0}$ is coefficient of horizontal effective stress at rest. This equation is used to calculate the unit skin friction of straight cylindrical pile. Table 3 explains briefly the pile behavior along with calculated normalized unit skin friction of piles at certain depths. For example, Equation 8 is used to determine the unit normalized unit friction closer to the normalized settlement ratio around 0.1 for straight piles. 


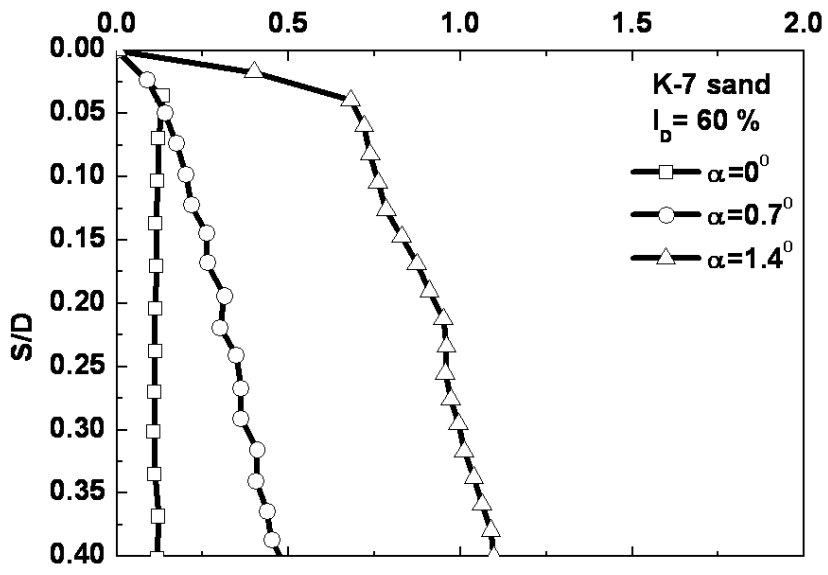

(a)

Skin friction, $P_{s}(k N)$

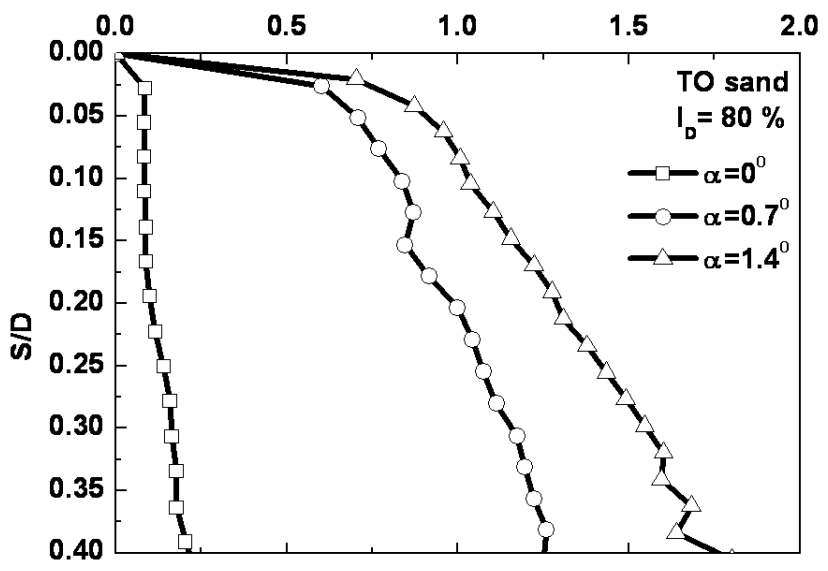

(b)

Skin friction, $P_{s}(k N)$

Fig. 10: Total skin friction of straight and tapered piles, measured in kN (a) K-7 sand and (b) Toyoura sand

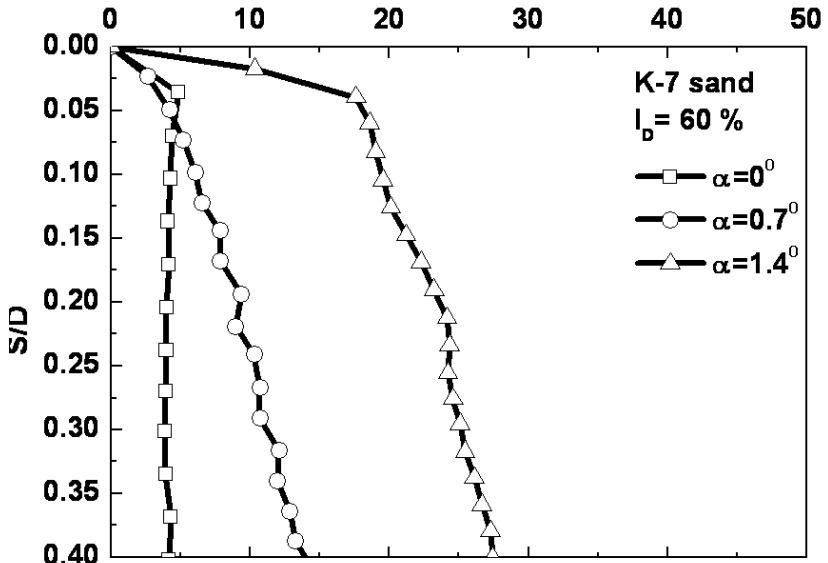

(a) Unit skin friction, $\mathrm{f}_{\mathrm{s}}(\mathrm{KPa})$

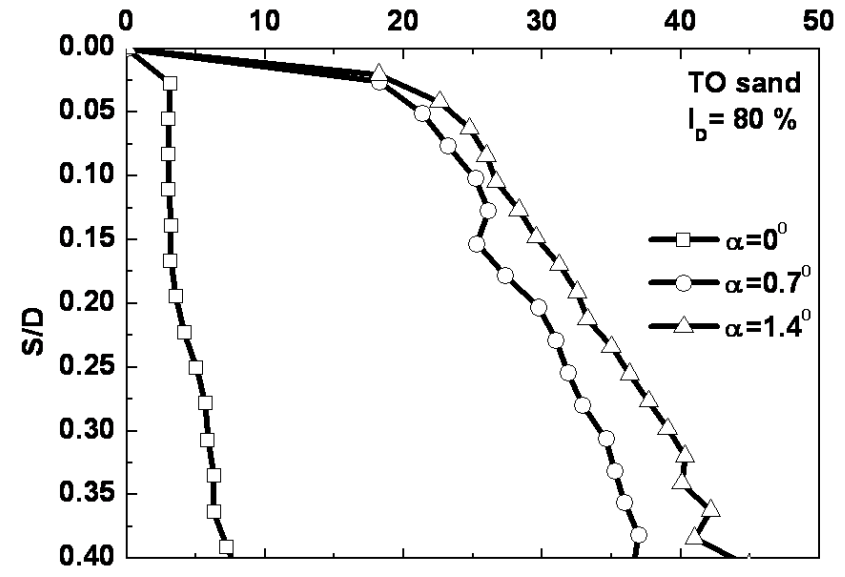

(b)

Unit skin friction, $f_{s}(\mathrm{KPa})$

Fig. 11: Unit skin friction of straight and tapered piles, measured in KPa (a) K-7 sand and (b) Toyoura sand

\section{EXPERIMENTAL RESULTS}

During pile penetration, the surface area affects the unit skin friction $\left(f_{s}\right)$. Hence, the unit friction is generally obtained by dividing surface area of pile to the skin friction considering average diameter of the pile such that:

$$
\begin{aligned}
& f_{s}=\frac{P_{S}}{A_{s}} \\
& A_{s}=\pi D_{a v}(L+\Delta L) . \\
& D_{a v}=\frac{D_{t}+d}{2}
\end{aligned}
$$

Here, $D_{\text {a }}$ is the average diameter of pile head $\left(D_{t}\right)$ and pile tip (d), $\mathrm{L}$ is the effective length of pile and $\Delta \mathrm{L}$ is the incremental depth of pile penetration expressed in metric system. The normalized unit skin friction was plotted with respect to normalized settlement ratio (S/D), where $S$ is the settlement and D is the pile tip diameter. Fig. 10 ( $a$ and $b$ ) reveals total skin frictions of K-7 and Toyoura sands under different types of piles penetration. In this case, tapering effects of piles were shown to be higher with increasing skin friction compared to straight pile. At 0.4 settlement ratio, K7 sand shows that the skin friction received by the most tapered piles is about 8 times with compared to straight pile. Even at small settlement ratio of 0.1 , the skin friction has increased about 5 times when the most tapered pile (T2) was penetrated into the ground. Similarly, TO sand has also received the similar trend. At 0.4 settlement ratio, the skin friction has increased about 7 times and at 0.1 settlement ratio, it has been increased about 8 times with compared to straight cylindrical pile. 


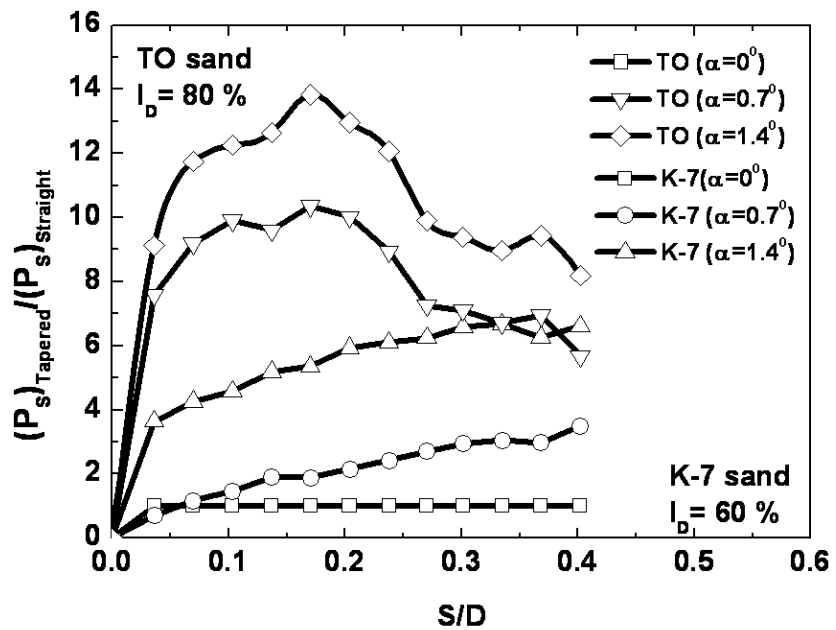

Fig. 12: Normalized total skin frictions ratios of K-7 sand and TO sand

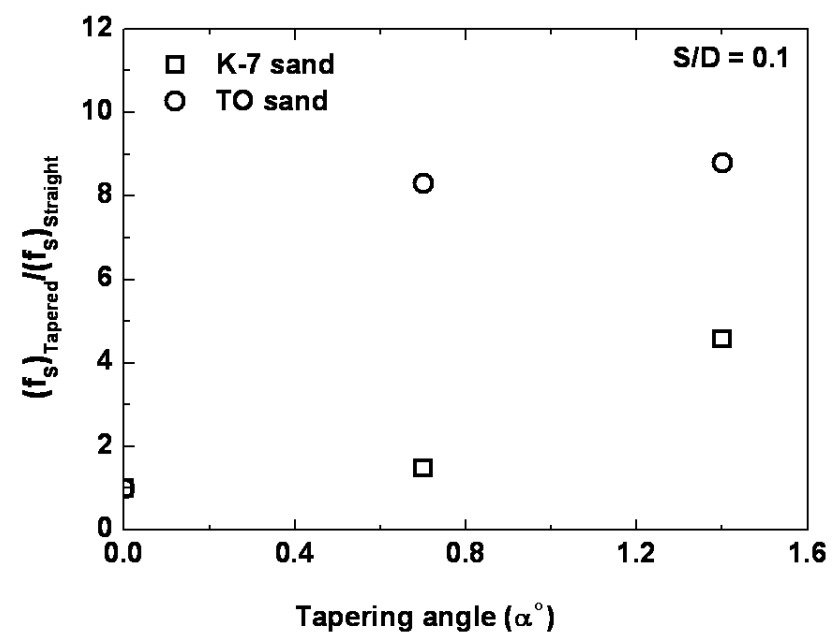

Fig. 14: Ratios of unit skin frictions of K-7 sand and TO sand with degree of tapering

Figs. 11(a) and 11(b) show the unit skin friction of K-7 sand and TO sand respectively. The unit skin friction has remarkably increased from the beginning of pile penetration in both K-7 and TO sands. At 0.4 settlement ratios, the unit skin friction of K-7 sand has increased about 9 times when the most tapered pile was penetrated. Meanwhile, the unit skin friction of TO sand has increased about 7 times at the same settlement ratio. Similarly, when the unit skin friction has been observed at small settlement ratio of $0.1, \mathrm{~K}-7$ sand, has received about 4 times while TO sand has received about 9 times with compared to straight cylindrical piles.

In addition, the mechanism of the skin friction can be compared with conventional straight cylindrical piles by taking ratios of skin friction of tapered pile to skin friction of straight pile. Fig. 12 shows the total skin friction ratios of straight and tapered piles respectively. At 0.4 settlement ratios, the total skin friction of K-7 sand has received about

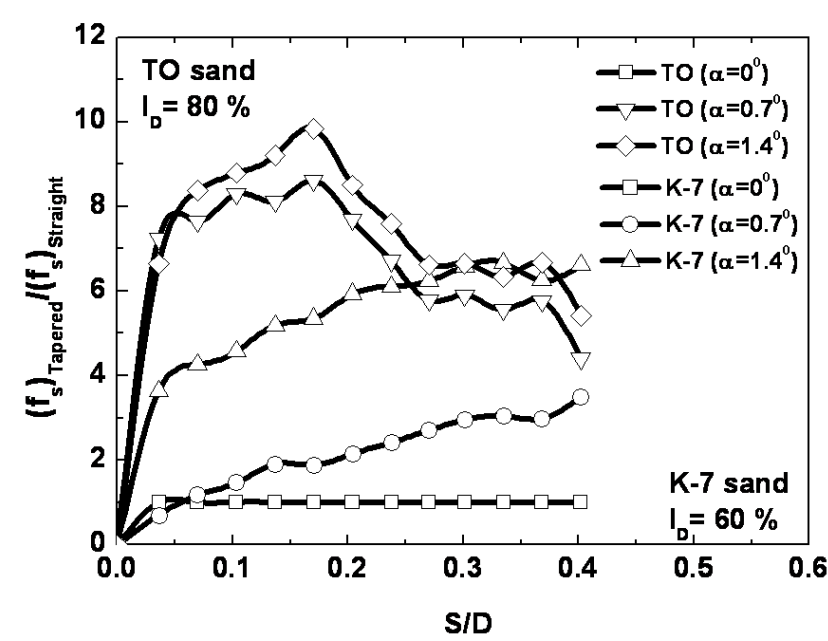

Fig. 13: Ratios of unit skin frictions of K-7 sand and TO sand

9 times higher value when the most tapered pile was penetrated in the ground. At the same time, TO sand has received about 8 times higher values. For design purpose, when 0.1 settlement ratio has been considered, K-7 sand has received 6 times and TO sand has received 12 times when the most tapered pile was penetrated into the ground respectively. Fig. 13 explains that the unit skin friction ratios of the most tapered pile at 0.4 settlement ratios have increased about 6 times on K-7 sand and 5 times on TO sand, respectively. When settlement ratio 0.1 has been taken, the unit skin friction ratios have increased about 6 times in K-7 sand. While in TO sand, the ratios have increased more with compared to K-7 sand and reached about 9 times.

In view of the fact that the design code of the foundation generally considers at 0.1 displacement ratio throughout the world, therefore, it is imperative to observe the effectiveness of the skin friction of tapered piles at this settlement. Hence, normalized ratios of unit skin frictions of both sands have been plotted against degree of tapering angle as shown in Fig. 14. On the account of different density of grounds, the unit skin friction at this depth is more pronounced. In the experiment, it is seen that $\mathrm{T} 2$ pile in TO sand is about 2 times greater with compared to medium dense K-7 sand. It can be noticed that the tapering effects increased in an exponential order. This exponential order of change in the unit skin friction with respect to degree of tapering might be another interesting key factor in the field of academic research.

\section{CONCLUSIONS}

The characteristics of the model test verify that the tendency of the skin friction of the tapered pile is greater than conventional straight cylindrical piles. In addition, the skin friction of tapered piles when normalized with its surface area, the skin friction has become greater than straight piles for all types of soils. The model test shows that the behavior of the most tapered pile governs larger skin friction. Toyoura 
sand in which the test was performed at relatively high density received higher skin friction. At the normalized total skin friction and unit normalized skin frictions, the skin friction has received the peak value at 0.2 settlement ratio which is more than 10 times with compared to straight pile. Afterwards the skin friction decreases all of sudden to certain level and maintains the steady state. This might be the effect of high relative density of the ground. Hence, it is clearly seen that the skin friction of tapered pile can be improved with increasing tapering angles.

Based on results of model tests and literature reviews, it can be stated that installation of tapered piles has benefits over straight cylindrical piles. When the tapered pile is used for foundation of any large structures, continuous increase in the skin friction increases the lateral pressure along with the increases the compressibility of soil around pile-ground interface as well as reduces the effects of dilatant behavior of soil.

\section{ACKNOWLEDGEMENT}

Authors are thankful to Er. M. Nakashima for extensive their support during experiment. The authors are also thankful to Mr. Y. Ishikawa and Mr. Y. Fujiwara for supporting to prepare the data. Our sincere gratitude goes to Geotechnical Laboratory, Kyushu University for providing fully equipped instruments and necessary supports to conduct the experimental work as well as research activities. Two anonymous reviewers are highly acknowledged for their critical suggestions to improve this manuscript.

\section{REFERENCES}

Dmokhovskii, V. K. , 1927, On the effect of the geometric shape of a pile on its capacity to resist. Tr. Moskov. Inst. Inzh. Zheleznodor. Transp., v. 6.

Fleming, W. G. K., Weltman, A. J., Randolf, M. F., and Elson, W. K., 1985, Piling Engineering Survey, Univ. Press, Halsted Press, N.Y., 380 p.

Japanese Geotechnical Enginereing Society, "The methods and description of soil tests", First revised version, pp. 59-64.

Manandhar, S., Yasufuku, N., and Shomura, K., 2009, Skin friction of taper-shaped piles in sands, Proceedings of the ASME $28^{\text {th }}$ International Conference on Ocean, Offshore and Arctic Engineering, OMAE 2009, Honolulu, Hawai, USA, pp. 1-10.

Miura, S. and Toki, S., 1982, A sample preparation method and its effect on static and cyclic deformation-strength properties of sand, Soils and Foundations, Japanese Geotechnical Society, v. $22(1)$, pp. 62-77.

Norlund, R.L., 1963, Bearing capacity of piles in cohesionless soils. Jour. of the Soil Mechanics and Foundation Division, ASCE, v. 117(8), pp. 1208-1226.

Peck, R.B., 1958, A study of the comparative behavior of friction piles. Spec. Rpt. 36, Hwy. Res. Bd., Wash., DC, pp. 72 p.

Terzaghi, K., 1942, Discussion of the progress report of the committee on the bearing value of pile foundations. Proceedings of the American Society of Civil Engineers, v. 68, pp. 311-323.

Yasufuku, N., Ochiai, H., Kwag, J. M. and Miyazaki, K., 1998, Effectiveness of critical state friction angle of volcanic ash soils in design applications, Proc. Int. Symp. on Problematic Soils, IS-Tohoku 98, Sendai, 1, pp. 189-193.

Yasufuku, N., Ochiai, H. P., and Ohno, S., 2001, Pile end-bearing capacity of sand related to soil compressibility, Soils and foundations, v. 41 (4), pp. 59-71.

Yasufuku, N. and Ochiai, H., 2006, Skin friction of nondisplacement piles related to simple shear mode with large strain state friction angle. Soils and foundations, v. 46 (4), pp. 537-544. 